\title{
II INTERNATIONAL MULTIDISCIPLINARY CONFERENCE MONGOLS: TRADITIONS AND MODERNITY 2019
}

The second International Multidisciplinary Conference Mongols: Traditions and Modernity took place on September 11-13, 2019 at the Russian State University for the Humanities (RSUH), Moscow. ${ }^{1}$ The meeting was organised by the Centre for Typological and Semiotic Folklore Studies (RSUH), the Institute for Oriental and Classical Studies (the Higher School of Economics, Russia), the Department for Estonian and Comparative Folklore (University of Tartu, Estonia), and the Institute for Mongolian Studies (National University of Mongolia, Mongolia).

This conference was established at 2016 as a regular international meeting, held once every three years and linking scholars interested in various aspects of Mongolian culture. The event aims to facilitate an exchange of knowledge on topics, approaches and projects related to Mongolian studies and associated academic fields (Tibetan, Turkic, Nomadic, Asian, Buddhist, Shamanic and other academic fields).

The term tradition was purposed as an overall framework for the meetings, taken in the fullest possible sense of linguistic and research meanings - traditions old and new, 'invented' and 'original', on-going and intermittent, individual and collective, and as found within diverse spheres of life, including in historical, cultural, folk, religious, social, political and other areas. Modernity is also to be understood broadly, embracing a variety of challenges to contemporary societies and cultures. Thus, presentations were welcome that covered any aspect of the humanitarian and social sciences related to the past and present of the Mongolian peoples and their neighbours.

In comparison with the first event the 2019 conference was significantly larger both in terms of organisers and partici- pants. Presentations and talks were given by researchers from Russia, Mongolia, China, Poland, the Czech Republic, Hungary, Estonia, Germany, Switzerland and France. Research specialised in various spheres of Mongolian studies representing various endeavours, theoretical schools and approaches. Working languages included Mongolian, English and Russian. The Conference included the following Sessions: I Mythological and Ritual Traditions; II Epic Traditions; III Tibetan and Mongolian Traditions of Buddhism; IV Songs and Poetic Genres; V Archival and Epigraphic Materials; VI Literature and Language; VII Society, State, Religion. ${ }^{2}$

The first day of the conference started with opening and welcoming speeches, given by Bayarhuu Jargalsaikhan (the first secretary of the Mongolian Embassy in Moscow) and Zayabaatar Dalai (Dean of the School of Arts and Sciences, National University of Mongolia; Director of the Institute for Mongolian Studies; Chairman of the National Council for Mongolian Studies, Government of Mongolia). Sergey Neklyudov (RSUH) continued the opening of the Conference with a lecture entitled Anthropological and Folkloristic Research in Mongolian Studies, touching on such questions as the aims and challenges of contemporary Mongolian studies, folkloristic and anthropological approaches in Mongolian studies, and future directions of research and joint projects.

The next section, Mythological and Ritual Traditions, included reports on various mythological figures, entities and concepts, as well as plots and practices connected to the mythological images popular in Mongolian tradition. The first part of this section, High Mythology, included reports devoted 
to Mongolian cosmology and cosmography, and deities of the higher pantheon. Alimaa Ayushjav (Mongolian Academia of Science) presented a paper entitled A Picture of the Universe in the Mythology of the Mongolian Peoples, based on historical sources and fieldwork materials, which looked at the central elements of Mongolian mythological images. Bair Dugarov (Russian Academia of Science) gave a talk On the Etymology of the Turkic-Mongolian Theonym Atai Ulaan Tengri, which was devoted to one of the most popular and important deities in various Mongolian traditions, Atai Tengri. Dugarov gave his version of the origin and etymology of the name of this deity and observed the peculiarity of the god's image in ritual, mythological and epic traditions. BadmaKhanda Tsybikova (Russian Academia of Science) gave a report on the Peculiarities of Representation of Buryat mythology in Worships and Taboo, which covered the interrelationship between myth and ritual through reflection on traditional mythological motifs in contemporary rites.

The second part of the section, Applied Mythology, included various cases united by the general theme of the function of traditional folk images in different spheres (social, economic, political, ideological) of contemporary Mongolian society. In her report The Role of Myth in the Creation of the Modern Mongolian Worldview and Cultural Community, Magdalena Szpindler (University of Warsaw, Poland) analysed use of images of Buddhist deities and mythological motifs in the legitimisation of state authority in various historical periods, including the contemporary one. The paper given by Nandinbilig Ganbaatar (National University of Mongolia) highlighted old and new rituals connected to the worship of a peculiar kind of oboo, i.e. ritual constructions made from stones and wood and devoted to nature spirits. Grégory Delaplas (Paris Nanterre University, France), in his report When the Picture Comes In, looked at the situation of overpowering an oppo- nent in a Mongolian wrestling match. He addressed his research to the consideration and analysis of modern practices and concepts that are popular within the community of Mongolian wrestlers - revered figures in Mongolian culture - in previous and modern periods. In her report A Magical Walking Tree: Landscape Mythology in the Contemporary Life of Professional and Local Communities, Alevtina Solovyeva (University of Tartu; RSUH; Higher School of Economics) presented a special case of contemporary landscape mythology: the narrative and ritual practice associated with the character the wrestler tree, Boh mod.

The first day of the conference was completed with a screening of the ethnographic film Times of Dreams, presented by Natal'ya Djushen and Alexey Yankovskiy. This was the premiere of the restored version, directed by the cinematographer Andris Slapiňš, together with the support of scientific consultants Yelena Novik and Yevgeniy Alekseyev. The film was shot between 1982 and 1991, and restored in 2019.

Thematic Sections II-IV were held on the second day of the conference. In the epic section five reports were presented on various traditions and aspects of Mongolian epic storytelling. Reports were based both on written samples from previous periods and on records of modern performances, preserved to a greater extent within Kalmykia and Inner Mongolia. In his report Tsagan Seleyeva (Russian Academy of Sciences) shared the results of his comparative study of epic traditions among the Oirat-speaking peoples of Russia, Mongolia and China. Dashdezhid Sukhbaataryn's (National University of Mongolia) presentation entitled Poetic Peculiarities in the Epic Story about Geser from Yun-Fu-Se, introducing her analysis of the written version of Geser, from the manuscript The Mongolian Woodblock Printing of the Geser in Beijing. Naranzandan's report (Central National University, China; RSUH), The Storyteller Tsogrov's Comments on Self-performed Stories, addressed 
the question of the personalities and figures of storytellers in epic traditions. The theme of personality and repertoire was continued in Boris Sengleyev's report (Russian Academy of Sciences) entitled Legends about the War Against Ablay-Taishi in the Folklore Cycle of Mazan-Batyr. The epic section was completed by Ellara Omakayeva's report (Kalmyk state University, Russia) The Image of the Horse in the Epic and Song Traditions of the Kalmyk and Oirats: Nominations of Species (Based on Published, Archival and Fieldwork Sources).

The section on the Tibetan-Mongolian traditions of Buddhism was made up of ten presentations. Karénina Kollmar-Paulenz's presentation (University of Bern, Switzerland) Radiant Sun Illuminating the Darkness of Sentient Beings tackled the issue of strategies for the spread of Buddhism among the Mongolian peoples in the 16th century. The report analysed the role of the personalities involved in this process, their methods and practices, as well as available sources, including written biographies. The report by Yana Lehman (the Higher School of Economics) continued the topic of Buddhist clerical biography, a genre that has spread and become popular in the Mongolian tradition. In this case Lehman focused on the life story of the fifth Noyon-hkutukhta Dandzanravja, a famous Mongolian poet, translator and dramaturge. Mungunchimeg Batmunkh (University of Bern), in her report entitled Danzanravjaa and the Red Protector 'Ter Minu', addressed the reception of Ter Minu's image in modern traditions and his connection to the cult of the revered Buddhist protective deity Jamsaran.

Anna TSendina (RSUH; Higher School of Economics) introduced an example of the interaction between Buddhist and local folk traditions. Her report, Dashdorj - Llama Prayer: Oral Legends About the Magical Power of the Sacred Word in Buddhism, was devoted to legends about the magical power of sacred texts, words, names of deities and even names of outstanding monks, in Mon- golian folklore. Agata Bareja-Starzyńska (Warsaw University, Poland) shared her research on Buddhist manuals. The report examines the spread of this genre among Mongolian priests and the general population, the peculiarities of the translation tradition (from Tibetan to Mongolian), and the function of this literature in the 16th-17th centuries and during the religious revival that began in the 1990s.

Rustam Sabirov's report (Moscow state University, Russia), Khubilgans in Modern Mongolia, introduced the peculiarities of reincarnation, and old and new traditions connected with it in modern Mongolia. The issue of modern perspectives and the transformation of traditional religious concepts also featured in the presentation by Yuliya Lyakhova (University of Bern), The Material and Spiritual in Mongolian Religious Life, which was dedicated to the motif of wealth in the discursive and ritual practices of contemporary Mongolia.

Three more reports were devoted to various ritual practices relating to the Buddhist traditions of the Buryat and Kalmyk peoples. Darima Zhamsuyeva's report (Russian Academy of Science) was devoted to an analysis of the features of the Buddhist ritual performance Tsam in Buryat tradition. In her presentation, Anastasiya Karpunina (RSUH) shared the results of her research on modern Buryat traditions and practices associated with such Buddhist attributes as prayer wheels. Bair Kovayeva (Kalmyk state University) shared with listeners the valuable data of a family biography, representing an example of the Kalmyk people's preservation and continuation of ritual traditions during the Soviet period. Veronika Belyayeva-Sachuk (Russian Academy of Sciences) presented research devoted to images of female deities and their origins in the modern tradition of the Sayan Buryats, touching on the gender aspects of the tradition.

The section dedicated to song and poetry focussed on the traditional poetic genres of 
various Mongolian peoples. The presentation by Veronika Kapišovská (Charles University, Check Republic), Dagur Songs Past and Present, introduced the song traditions of the Dagur Mongols. Lidiya Dashiyeva (Russian Academy of Science) presented her musical research on western Buryat song traditions. The report made by Boskha Borlykova and Badma Menyayev (Kalmyk state University) was dedicated to the modern song traditions of the Khoshut Mongols. Two reports introduced research on the contemporary conditions of the traditional genre of well-wishing among Kalmyk and Oirat peoples. Omakayeva and Kovayeva focused on a comparative study of this genre among Kalmyks and Mongolian Oirats while Borlykova, Kovayeva and Miryalkhan Nadmittere (Inner Mongolia University, China) devoted their presentation to comparative research into well-wishing among the Kalmyks and Chinese Oirats.

The last day of the conference included Sections V-VII, the archival and epigraphic materials section, including a paper by Dulam Sendenjav (University of Culture and Arts, Mongolia) that acquainted colleagues with the results of his study of petroglyphs and their perceived connections with Mongolian state symbols. The report by Borlykova and Menyayev, Kalmyk Folklore Material in the Scientific Archive of the Russian Geographical Society, and the report by Dmitriy Nosov (Russian Academy of Sciences) The Rumoured Existence of a Giant Worm ... Was Confirmed: Mongolian not Fairy-tale Prose in the Records of V. A. Kazakevich (1896-1937), introduced important archival discoveries and outlined the roles they played in the study of past and present tradition.

The literature and language section included two reports on the modern Mongolian literature and two reports devoted to linguistic research. Lidiya Skorodumova (Higher School of Economics) introduced her paper In Thrall to Tradition: Mongolian Literature in the First Quarter of the 20th Century. Svetlana Tsedenova (Kalmyk state University) presented her research on the literary traditions of the Oirat Mongols in China. Linguistic topics were presented by Îliya Gruntov (Russian Academy of Sciences), Ol'ga Mazo (RSUH; Higher School of Economics), and Anna Tsendina (RSUH; Higher School of Economics) in their presentation The Current State of the Khamnigan Language in Mongolia, based on contemporary field research, and by Attila Rákos (Eötvös Loránd University, Hungary) in his presentation Tradition and Innovation in the Written Languages of the Oirats.

The final section, Society and State, was made up of nine reports relating to various aspects of the relationship between society, state and religion, citing various periods and examples of Mongolian peoples and their neighbours. Peter Sobkowiak (University of Bern), in his report The Legislation System of the Russian Empire in the First Half of the 19th Century and the Legal Status of 'Shamanic Faith' in Buryatia, introduced the development and spread of the concept of 'shamanism'. Natal'ya D'yachenko's report (Altai State Pedagogical University, Russia) focused on the armed uprisings of the 1930s, viewing them as a consequence of 'the left course' in Soviet policy. The presentation by Kikee Doma Bhutia (University of Tartu) introduced the situation of Tibetan communities in contemporary Sikkim, traditional motifs found in political prophecies and their contexts. The reports by Carsten Friede (University of Bonn) and Oyuntuya Shagdarsuren (University of Bonn, Germany) were devoted to analysis of the practical aspects of the functioning of modern Mongolian society. Friede presented an analysis of contemporary communication practices and the behaviour of mobile operators in modern Mongolia. Oyuntuya presented her gender studies research into public administration in Mongolia. The report given by Sesegma Zhambalova (Russian Academy of Science), Traditional Technologies of Nomadism among the Mongols in the 20th and 21st 
Centuries, on the contrary was devoted to the traditional elements in modern Mongolian life. Two reports in this section were also devoted to the review and analysis of the folklore and ritual traditions of the Tuvans and Khamnigans of Mongolia. Zhanna Yusha (Russian Academia of Science) presented the report Tuvinians of Mongolia: The Current State of Folklore. Battuya Ochir (University Mandakh, Mongolia), in the paper Ethnical Processes within Communities of Mongolian Khamnigans, shared her observation and analysis of the situation of the Khamnigan peoples in Mongolia in the 20th and 21st centuries.

The conference provided an opportunity to get acquainted with a variety of topics and research projects relating to Mongolia, Mongolian peoples and their neighbours, create new and strengthen existing professional ties, as well as generating new ideas and plans for the Mongolian and Asian studies research area.

$$
\begin{array}{r}
\text { Alevtina Solovyeva } \\
\text { (University of Tartu; } \\
\text { National Research University } \\
\text { Higher School of Economics) }
\end{array}
$$

\section{Notes}

1 This event was financially supported by the National Council for Mongolian Studies, Government of Mongolia and the Ministry of Education, Culture, Science and Sports, Mongolia.

2 See Solovyova and Khristoforova 2019.

\section{References}

Solovyova, Alevtina and Ol'ga Khristoforova, eds. 2019. Mongols: Traditions and Modernity. III Readings in the Memory of Elena S. Novik. Abstracts. Moscow, RSUH, September 11-13, 2019. Moscow: RSUH. http://www. ruthenia.ru/folklore/pdf/2019_tez_mongol.pdf?fbclid=IwAR3SS_LpN_QRGP d8iMIZNEfxKYcCan9I9MvEQXjircvGPizSPlQbpg8XXM (accessed March 2, 2020). 